Clemson University

TigerPrints

$5-9-2011$

\title{
Writing Development over Time: Examining Preservice Teachers' Attitudes and Beliefs about Writing
}

Anna H. Hall

Clemson University, ah2@clemson.edu

Jennifer Grisham-Brown

Clemson University

Follow this and additional works at: https://tigerprints.clemson.edu/eugene_pubs

Part of the Education Commons

\section{Recommended Citation}

Anna H. Hall \& Jennifer Grisham-Brown (2011) Writing Development Over Time: Examining Preservice Teachers' Attitudes and Beliefs About Writing, Journal of Early Childhood Teacher Education, 32:2, 148-158, DOI: 10.1080/10901027.2011.572230

This Article is brought to you for free and open access by the Eugene T. Moore School of Education at TigerPrints. It has been accepted for inclusion in Publications by an authorized administrator of TigerPrints. For more information, please contact kokeefe@clemson.edu. 
Writing Development over Time:

Examining Preservice Teachers’ Attitudes and Beliefs about Writing Donald Graves (1983), a pioneer in the field of early childhood writing, described a child's natural desire to write in his classic book, Writing: Teachers \& Children at Work.

Children want to write. They want to write the first day they attend school. This is no accident. Before they went to school they marked up walls, pavements, newspapers with crayons, chalk, pens or pencils... anything that makes a mark. The child's marks say, "I am” (p. 3).

It is important as educators to foster this natural desire, not only because children want and need to express themselves, but also because writing ability has been found to be a key indicator of school success and successful participation in the workplace (Graham, Harris, Fink, \& MacArthur, 2001; Norman \& Spencer, 2005).

NAEYC (National Association for the Education of Young Children; 2009) defines early childhood as the years from birth through age 8 and suggests that early childhood standards are meant to support teacher preparation of professionals. The National Assessment of Education Progress (NAEP) report card on writing does not report writing scores for children in this age range, but the scores reported for older children indicate a deficiency in the preparation of writing teachers at the early childhood level and beyond. In 2007, NAEP reported that only 33\% of eighth graders in America scored at or above proficient in the area of writing (Norman \& Spencer, 2005). Although fourth graders were not included in the latest 2007 NAEP writing report, the low 
percentage of eighth graders $(33 \%)$ at a proficient level continues to discourage early childhood writing teachers (Salahu-Din, Persky, \& Miller, 2008).

The National Commission on Writing for America's Families, Schools, and Colleges was established in 2002 to focus national attention on the teaching and learning of writing. The first report issued by this commission was titled The Neglected " $R$ ": The Need for a Writing Revolution (Sterling 2003). The goal driving this report was to focus attention on the importance of writing for all students in the $21^{\text {st }}$ century. The report recommended increasing writing time substantially and providing resources to make increased instructional time possible (Sterling, 2003). The National Commission on Writing web site describes this report's recommendations along with resources to help teachers achieve these goals (http://www.writingcommission.org/). Richard Sterling, past director of the National Writing Project, suggests that policy statements and classroom practice are not often closely linked. He believes that it is the creative and thoughtful ideas of teachers that drive the shift towards making writing a priority in early childhood classrooms (Sterling, 2003).

Despite national concerns about the importance of writing instruction, little emphasis is placed on teaching writing in most teacher education programs. Although there is a strong research base that recommends the integration of reading and writing (Skeans, 2000), most teacher certification programs spend the majority of their time focusing on reading instruction and ignoring the importance of preparing teachers to provide writing instruction (Norman \& Spencer, 2005).

According to constructivist theory, preservice teachers' beliefs (i.e., those that influence how they conceptualize teaching) are well-established and resistant to change 
by the time they enter college (Cross, 2009; Ng, Nicholas, \& Williams, 2010). Although preservice teachers do not receive as much coursework that emphasizes teaching writing to children as they do for teaching reading, they do enter teacher education programs with years of their own writing experiences from their K-12 educations while having observed many examples of writing instruction. These early experiences help shape beliefs and attitudes towards writing and often determine the pedagogical decisions made by new teachers with regard to writing instruction (Norman \& Spencer, 2005; Street, 2003).

Examining the writing histories of preservice teachers is critical because beliefs and attitudes can have an effect on future teacher performance and student outcomes (Robinson \& Adkins, 2004). In their theory of reasoned action, Fishbein and Ajzen (1975) describe a strong chain of connections that show the evolution of beliefs to attitudes, attitudes to intentions and finally, intentions to actions. Since beliefs and attitudes have been clearly linked to teacher actions (Weinburg, 2007), understanding the epistemological beliefs of preservice teachers can provide insight into ways of improving teacher writing instruction $(\mathrm{Ng}$ et al., 2010).

Although preservice teachers' beliefs about writing are well-established by the time they enter teacher education programs, promising research has been conducted that suggests their beliefs are evolving and that it is possible to help them develop into "selfregulated, critically reflective professionals" (Ng et al., 2010, p. 278). Courses aimed at influencing the beliefs of preservice teachers have many features in common that help produce desirable change including teachers actually engaging in writing, examining and reflecting on their current beliefs about writing, reflecting on their practice teaching, 
participating in collaborative group work, and learning about alternative teaching models (Beswick, 2006).

As teacher educators strive to help preservice teachers examine and possibly change their beliefs, they not only help develop reflective teachers, but they also help develop teachers with a strong sense of efficacy. Graham et al. (2001) describe teachers' sense of efficacy as the confidence that they can perform actions that lead to student learning. In order to carry out tasks successfully, teachers must also believe in their abilities to accomplish desired outcomes (Tschannen-Moran \& McMaster, 2009). Teachers make judgments of their self-efficacy based on verbal encouragement that they have received, the success or failure of teacher models, perceptions of past experiences of teaching, and the level of emotional connection they feel when they anticipate and practice teaching (Bandura, 1997; Tschannen-Moran \& McMaster, 2009). Although many studies have been conducted that examine the connection between early childhood preservice teachers' attitudes, beliefs, and self-efficacy regarding mathematics and science, little research of this kind has been conducted regarding preservice teachers' attitudes and beliefs about writing.

In this article, two focus groups conducted to examine the beliefs and attitudes of preservice preschool and elementary teachers towards writing are described. The focus groups comprise one component of a broader research project that will create and validate a tool for measuring preservice teachers' attitudes towards writing to be used in conjunction with the Writing Orientation Scale (WOS) which measures teachers' beliefs and orientation towards the teaching of writing (Graham et al., 2001). The following research questions guided the focus groups: (a) What are preservice teachers' attitudes 
and beliefs about writing? (b) How have experiences over time affected preservice teachers' attitudes and beliefs about writing? And (c) How do preservice teachers' attitudes and beliefs about writing influence their plans to teach writing in the future?

\section{Method}

Focus groups are widely used in qualitative research to uncover unique perspectives within an environment where participants can interact, share, and learn from one another. When participants are invited to validate and challenge each other's ideas, a rich body of knowledge can be acquired (Lehoux, Poland, \& Daudelin, 2006). The purpose of conducting the focus groups described in this article was to gather information about early childhood and elementary preservice teachers' attitudes and beliefs about writing and their plans for future writing instruction. The results of these focus groups will be used to help create a survey that measures preservice teachers' attitudes towards writing.

\section{Participants}

Participants were 14 preservice teachers ranging in age from 18-22 years at a large state university in central Kentucky. Participants were selected based on their status as student teachers during the semester in which the focus groups were conducted. All participants were female and were in their final semester of the teacher education program. The first focus group included eight Interdisciplinary Early Childhood Education (IECE) majors (preparing to work with families and young children, birth-5 years with and without disabilities) and the second focus group included six Early Elementary Education (EEE) majors (preparing to teach Kindergarten- $5^{\text {th }}$ grade). All preservice teachers were currently placed in early childhood classrooms (preschool- $3^{\text {rd }}$ 
grade) to perform their student teaching requirements. They also attended seminars on campus to assist in developing their teaching portfolio to be used for future job interviews.

\section{Data Source and Analysis}

A semi-structured group interview or focus group was conducted in two sites. The first focus group (IECE majors) was conducted in the classroom of the participating students following a regularly scheduled seminar. The second focus group (EEE majors) was conducted at a local elementary school following a regularly scheduled student teacher meeting.

Participants were recruited for the focus groups during their student teaching seminars on campus. The two instructors of the student teaching seminars were asked to make a class announcement inviting students to speak with a researcher, in a small group setting, about their attitudes towards writing and the effects these attitudes may have on their choice of instructional strategies for teaching writing. After the class announcement, eight students majoring in IECE and six students majoring in EEE volunteered to participate in the groups. The students put their names and email addresses on a sign-up sheet that the instructors then passed along to the researcher. The researcher contacted volunteers through email to arrange the best day and time for each group.

The researcher began the focus groups by describing rules and procedures for the group interview, and asking participants to read and sign consent forms. The researcher then asked 10 open-ended questions to allow participants' to share their beliefs and attitudes towards writing as well as their plans for teaching writing in the future. The first eight questions were adapted from a questionnaire developed by Chris Street (2003) 
and published in his article entitled "Pre-service Teachers' Attitudes about Writing and Learning to Teach Writing: Implications for Teacher Educators". In addition to the eight questions adapted from Street's questionnaire, two follow-up questions were asked to explore how participants planned to teach writing in the future: (a) "what types of writing instruction methods do you plan to use as a teacher?" and (b) "how many times per week do you plan to teach writing?"

Participants in each group sat together in a round table format and took turns answering questions asked by the researcher. Responses were recorded on tape and later transcribed verbatim. Analysis involved organizing the data according to answers to specific questions asked of participants in each of the two focus groups. Transcripts were analyzed through grounded theory (Maxwell, 2005) and issues and topics in the transcriptions were used to identify themes. The lead author and a faculty advisor independently made a list of identified themes by segmenting the text into words, phrases and sentences. The lead author identified the prevalence of key phrases (e.g., organizing ideas) using a frequency distribution of participants' responses. The faculty advisor developed codes for key themes (e.g., writing mechanics) that emerged with each question and used the codes to categorize each participant response. The lead author and faculty advisor then met to discuss discrepancies and reached an agreement on shared themes.

\section{Results}

Analyses of focus group data indicate a range of important issues that may influence the field of early childhood teacher education. Most (64\%) participants viewed themselves positively as writers. Participants' views were related to various influences of 
people and experiences over their K-12 education and college careers. Results are presented in five areas: (a) positive and negative writing experiences, (b) easy and hard aspects of writing, (c) personal uses of writing, (d) strengths and weaknesses as writing teachers, and (e) plans for using writing in the classroom. Each area, with supporting evidence, is described below. The percentages of participant responses are listed parenthetically after each key theme.

Positive and Negative Writing Experiences

When asked to describe a positive writing experience in or out of school, participant answers fell into two broad categories: (a) experience with teaching strategies, and (b) creative writing opportunities. Teaching strategies that fostered positive experiences for students include journaling (20\%), publishing (50\%), and meaningful feedback and praise (21\%). It was made clear by half of the participant responses that having their writing published or showcased was a positive experience in their writing histories and contributed to positive attitudes towards writing. Two participants described their experiences with showcased writing:

"I wrote fictional pieces at home regularly. I once showed one to my $7^{\text {th }}$ grade writing teacher and she showcased it."

"In English 104, I had a really encouraging teacher and he would want to read some of my papers to the class."

Creative opportunities included interesting writing assignments (36\%) and freedom when choosing writing topics $(50 \%)$. When asked to recount a positive writing experience, one participant stated: 
“Any time when I've had an opportunity to write creatively or choose my topic. My senior English teacher in high school gave us a variety of topics that we could choose from or we could choose our own topic related to the content and we'd come in every day for the 50 min and she'd play music, and she even got our opinion on that, what music we liked and we would just write and she would give us some feedback."

When asked to describe a negative writing experience in or out of school, participant answers focused primarily on critical feedback from teachers including the famous "red marks" on papers (36\%) and instances where students and teachers just did not agree (29\%). At times the disagreements were about the quality of work and other times about controversy over content. One participant described her experience:

"When I get my papers back and they have red marks all over them, I mean it's nice to have feedback but it still feels negative."

Another complaint made by participants was feeling uninterested in school writing assignments (14\%). Participants stated that when their writing classes lacked creative opportunities (43\%) and they were made to write about assigned topics or engage in technical writing, their interest waned.

\section{Easy and Hard Aspects of Writing}

When participants were asked to describe the easiest parts of the writing process, many felt that choosing topics and coming up with ideas (43\%) were easy. Other participants felt that organizing their ideas $(21 \%)$ was the easiest part. One participant stated:

"The easiest part for me is thinking about something to write and just writing." 
When asked to reflect on the hardest parts of the writing process, what some participants thought was easy, others found difficult. Some participants found getting started with a writing assignment (29\%), organizing their ideas $(21 \%)$ and making ideas flow (14\%) to be the most difficult parts of the writing process. Others felt disengaged when asked to write technically (14\%) or to write about assigned topics (29\%). One participant described her struggles with these aspects of writing:

"The hardest part is organizing what I write and making it flow and I also think it's hard to write when I don't like the topic, I'm kind of stubborn."

Although some participants felt that writing mechanics (e.g., ability to spell, edit and use proper grammar and sentence formation) were an easy part of the writing process (21\%), more participants described the use of writing mechanics as difficult and not enjoyable (36\%).

\section{Personal Uses of Writing}

When participants were asked to describe personal uses of writing, their responses fit into three categories: (a) communication with others, (b) recording feelings/selfexpression, and (c) school related uses. To communicate with friends, participants primarily used email and social networking websites (e.g., Facebook; 50\%). In order to record feelings and express themselves through writing, some used journaling (43\%), blogging (21\%), poetry (7\%) and picture book writing (7\%). Finally, to enhance their performance in college, participants used assignment to-do lists $(29 \%)$, calendars (7\%), and notebooks for recording teaching ideas (14\%). One participant described her personal uses for writing: 
“I feel like I don't have time to write anything more than a couple of sentences so I write things on my calendar at home but just so I can remember what's coming up. This may sound silly, but I also like to write status updates on my blog and I like to email people. Half the time I'm writing these things just for me, it keeps me sane."

\section{Strengths and Weaknesses as Writing Teachers}

When asked to think about themselves as writing teachers in the future, participants listed strengths that fell into three categories: (a) personality characteristics, (b) teaching strategies, and (c) setting up the environment. Personality characteristics that participants felt were strengths included being enthusiastic $(14 \%)$, empathetic $(7 \%)$ and encouraging (7\%). Teaching strategies that participants felt were strengths included breaking down the writing process for students (14\%), allowing for topic choice (14\%) and creative expression (7\%) and being organized with their writing instruction (7\%). Finally, participants felt that they would be able to set up a positive writing environment by providing ample writing opportunities throughout the day (29\%) and by using a classroom set-up (14\%) that would encourage writing development. One participant stated:

"I think my strength will be giving them opportunities and creating an environment that always promotes writing."

Participant responses about their weaknesses as future writing teachers fell into three categories as well: (a) mechanics, (b) teaching strategies, and (c) feedback. Participants that struggled with spelling and grammar (50\%) in their own writing felt that it would be a weakness when working with students. Others worried about teaching 
handwriting (7\%) and coming up with enough ideas for writing lessons (14\%). One participant described her struggles:

"A big weakness is that I always want to come up with new opportunities, new ways to bring writing to them and I have trouble coming up with those new ways sometimes. I get down on myself for having trouble always coming up with something new."

Some participants felt that correcting papers and assessing young writers (14\%) would be their biggest weaknesses. Finally, one participant mentioned the struggle that she envisioned with balancing creative writing opportunities with assigned topics and writing prompts:

"My weakness is figuring out how to give them time to write about what they want but also teaching them that you can't always write about what you want to. Helping them find a balance in writing what they want and what they need to write sometimes."

\section{Plans for Using Writing in the Classroom}

Participants were asked what types of writing instruction methods they planned to use in the future, how often they planned to teach writing, and how they planned to use writing in their professional careers. Some participants planned to use process writing methods (e.g., the Writing Workshop approach; 14\%) which focus on the writing process instead of the finished product (Tompkins, 2007). Other participants did not describe one distinct teaching method, but instead offered different types of writing activities that they would use including journaling (36\%), morning message (21\%) and whole group writing (7\%). Although many participants planned to allow student choice during writing time 
(50\%), others planned to use assigned topics (21\%) and lessons that were solely focused on handwriting and letter formation (7\%). One participant stated:

"I really like the idea of a morning message, they have to figure it out on their own sort of. I would help them draw pictures and write about them. I think in kindergarten, they'd be trying to figure their sounds out or their blends."

Although nearly half of the participants responded that they would have specific writing times throughout the week (43\%), answers varied tremendously on the amount of time that would be spent on writing instruction. $57 \%$ of participants did not plan to teach writing at a specific time and $29 \%$ said writing would be embedded into the curriculum throughout the day. One participant describes her plan for instruction:

"I would make time for writing every day but I would be very creative in how I would do it. I would allow opportunities on the computer or through a journal. I would have them respond to experiences and definitely spend time on it every day. But it would be very embedded, not a specific writing time, maybe a whole group setting."

Participants discussed many ways that they would use writing in their professional careers. Their responses fell into the following categories: (a) communication with families, (b) communication with colleagues and the community, and (c) writing related to students. In order to communicate with families, participants planned to use classroom newsletters (43\%), daily notes (57\%), and emails (21\%). Planned communication with colleagues and the community included classroom blogs (21\%), emails (29\%), and written material to be shared during professional development opportunities (14\%). Finally, participants planned to write about individual students 
while collecting data for individualized education plans (IEP's), behavior charts, and any type of classroom assessment that would be included in day-to-day teaching (21\%). One participant stated:

“I see myself writing a lot of IEP's and assessments but the things I look forward to writing are communications with parents and maybe a class website that could be open to parents, other teachers and specialists."

\section{Conclusions and Implications}

The data from these focus groups provide valuable information about the importance of examining preservice teachers' attitudes and beliefs about writing. The following three broad themes emerged related to key influences in the development of positive and negative attitudes towards writing: (1) having writing published or showcased increases positive attitudes towards writing (2) creative opportunities and process-oriented teaching strategies provide the most meaningful writing experiences, and (3) negative feedback from teachers adversely impacts self-confidence in writing skills and leads to negative attitudes towards writing.

Creative writing opportunities have been reported as meaningful in similar studies because they allow for self-expression and reflection (Norman \& Spencer, 2005). With these findings in mind, it is important for teacher educators to consider giving their own students creative writing opportunities and using process-oriented teaching strategies such as the Writing Workshop approach (Tompkins, 2007). By modeling these effective strategies with their own students, it is more likely that preservice teachers will learn the importance of using similar strategies when they become teachers in the future. These 
findings also suggest that teacher educators should model giving positive feedback and praise along with valuing student writing through showcasing and publishing their work.

Bandura's (1977) social learning theory describes how people learn from one another through continuous reciprocal interactions with their environment explaining the extreme influence of negative and positive writing experiences over time.

It is important to keep in mind that teacher actions (e.g., showcasing work, giving positive feedback) not only affect the self-confidence of developing writers but may also affect the self-efficacy of future teachers (Graham et al.) Tschannen-Moran and McMaster (2009) stated that, “Teacher self-efficacy is a teacher's perceived capability to impart knowledge and to influence student behavior, even that of unmotivated or challenging students" (p.228). By helping preservice teachers examine their own attitudes and beliefs about writing, teacher educators can help continue to build, or in many cases, rebuild their students' self-confidence in their writing abilities. Restored self-confidence and increased knowledge of pedagogy will ensure a high sense of teacher self-efficacy in preservice early childhood writing teachers.

Three themes related to views of writing instruction and pedagogical decisions for the future emerged from the focus groups. These were: (1) embedding writing opportunities throughout the day helps provide quality writing instruction, (2) preservice teachers who struggle with writing mechanics are hesitant about teaching these skills to their future students, and (3) preservice teachers do not agree on one specific methodology for teaching writing or the amount of time that they will teach writing in the future. 
Knowledge of preservice teachers' future plans for writing instruction can be used to further study the relationship between personal attitudes and beliefs about writing and the effects these attitudes and beliefs have on pedagogical decisions. Current research demonstrates that positive writing experiences at the college level can help change wellestablished negative attitudes towards writing (Beswick, 2006). The findings from these focus groups encourage teacher educators to focus not only on building preservice teachers' confidence in the teaching of writing, but also on helping preservice teachers become better writers themselves. For example, if a student struggles with spelling, a college instructor could model pulling misspelled words out of the student's writing journal to create a weekly individualized spelling test. This strategy would improve the preservice teacher's spelling abilities while also teaching her an effective strategy for helping her students who struggle with spelling in the future.

Further research will provide opportunities for both preservice teachers and teacher educators that will enhance literacy courses at the college level ( $\mathrm{Ng}$ et al., 2009). By examining beliefs about writing as well as personal strengths and weaknesses, preservice teachers will understand more about writing development and will possibly become more open to learning about alternative teaching methods (e.g. embedding). Through this same reflective process, teacher educators will learn about the knowledge, skills, and beliefs of their students and be able to use this information to shape coursework and field-based experiences. For example, coursework may focus more on specific research-based methodologies for teaching writing and give preservice teachers clearer expectations of how often and in what ways they should teach writing in their 
future classrooms. Donald Graves (1983) states the importance of seeing yourself as both a writer and teacher before entering the classroom:

The teaching of writing demands the control of two crafts, teaching and writing. They can neither be avoided, nor separated. The writer who knows the craft of writing can't walk into a room and work with students unless there is some understanding of the craft of teaching. Neither can teachers who have not wrestled with writing, effectively teach the writer's craft....There is a road, a journey to travel, and there is someone to travel with us, someone who has already made the trip (pp.6-7).

Keeping this in mind, it is crucial for preservice teachers to examine their own beliefs about writing before traveling the road of teaching others. Teacher educators must travel with preservice teachers through their college courses on writing and help them learn to develop these two inseparable crafts. 


\section{Appendix}

\section{Focus Group Questionnaire}

1. Describe yourself as a writer.

2. Describe a positive writing experience you have had (in or out of school).

3. Describe a negative writing experience you have had (in or out of school).

4. What is the easiest part of writing for you? What do you do well?

5. What is the hardest part of writing for you? What do you feel you need to work on?

6. What kind of writing do you do just for you?

7. What makes a piece of writing excellent?

8. As you think about your professional life as an educator, what sort of written contribution do you see yourself making (e.g., writing for parents, colleagues, administrators)?

9. As you think of yourself working with students, helping them develop as writers: What do you see as your strengths? How do you think you will most help writers? What do you anticipate having to work on as a teacher of writing?

10. What types of writing instruction methods do you plan to use as a teacher? How many times per week do you plan to teach writing?

(Adapted from Street, 2003) 


\section{References}

Bandura, Albert. (1977). Self-efficacy: Toward a unifying theory of behavioral change. Psychological Review, 84, 191-215.

Bandura, A. (1997). Self-efficacy: The exercise of control. New York: Worth Publishers. Beswick, K. (2006). Changes in preservice teachers' attitudes and beliefs: The net impact of two mathematics education units and intervening experiences. School Science and Mathematics, 106(1), 36-47.

Cross, D.I. (2009). Alignment, cohesion, and change: Examining mathematics teachers' belief structures and their influence on instructional practices. Journal of Mathematics Teacher Education, 12(5), 325-346.

Fishbein, M., \& Ajzen, I. (1975). Belief, attitude, intention, behavior: An introduction to theory and research. Reading, MA: Addison-Wesley.

Graham, S., Harris, K. R., Fink, B., \& MacArthur, C.A. (2001). Teacher efficacy in writing: A construct validation with primary grade teachers. Scientific Studies of Reading, 56(2), 177-202.

Graves, D.H. (1983). Writing: Teachers and children at work. London: Heinemann Educational Books.

Lehoux, P., Poland, B., \& Daudelin, G. (2006). Focus group research and the "patient's view". Social Science \& Research, 63, 2091-2104.

Maxwell, J. A. (2004). Qualitative research design: An interactive approach. Thousand Oaks: Sage Publications, Inc.

National Association for the Education of Young Children (2009). NAEYC standards for early childhood professional preparation programs. Retrieved March 31, 2010 
from http://www.naeyc.org/files/naeyc/file/positions/ProfPrepStandards09.pdf.

Ng, W., Nicholas, H., \& Williams, A. (2010). School experience influences on preservice teachers' evolving beliefs about effective teaching. Teaching and Teacher Education: An International Journal of Research and Studies, 26(2), 278-289.

Norman, K.A., \& Spencer, B.H. (2005). Our lives as writers: Examining preservice teachers' experiences and beliefs about the nature of writing and writing instruction. Teacher Education Quarterly, 32(1), 25-40.

Robinson, S.O., \& Adkins, G.L. (2002). The effects of mathematics methods courses on preservice teachers' attitudes towards mathematics and mathematics teaching. Retrieved from ERIC database. (ED474445)

Salahu-Din, D., Persky, H., \& Miller, J. (2008). The nation's report card: Writing 2007. Retrieved March 20, 2010, from http://nces.ed.gov/pubsearch/pubsinfo.asp?pubid=2008468

Skeans, S.S. (2000). Reading...with pen in hand! English Journal, 89(4), 69-72.

Sterling, Richard. (2003). Why writing matters: An invitation to share your ideas about writing in the 21st century. Voices from the Middle, 11(2), 5.

Street, C. (2003). Pre-service teachers' attitudes about writing and learning to teach writing: implications for teacher educators. Teacher Education Quarterly, 30(3), $33-50$.

Tompkins, G.E. (2007). Teaching writing: Balancing process and product $\left(5^{\text {th }}\right.$ ed.). Saddle River, NJ: Prentice Hall.

Tschannen-Moran, M., \& McMaster, P. (2009). Sources of self-efficacy: Four professional development formats and their relationship to self-efficacy and 
implementation of a new teaching strategy. The Elementary School Journal, $110(2), 228-245$.

Weinburgh, M. (2007). The effect of tenebrio obscurus on elementary preservice teachers' content knowledge, attitudes, and self-efficacy. Journal of Science Teacher Education, 18(6), 801-815. 